\title{
MENOLAK SUBORDINASI GENDER BERDASARKAN PENTINGNYA PERAN PEREMPUAN DALAM PEMBANGUNAN NASIONAL MENJELANG BONUS DEMOGRAFI 2035
}

\author{
Lilis Karwati \\ Pendidikan Masyarakat, FKIP, Universitas Siliwangi \\ liliskarwati@unsil.ac.id
}

\begin{abstract}
Abstrak
Dalam menghadapi bonus demografi pada tahun 2035 tentunya menjadi hal yang harus kita persiapkan dari sekarang termasuk dalam menonsubordinasikan kaum perempuan. Adapun Tujuan dalam penelitian ini yaitu untuk mengetahui apa saja dampak yang ditimbulkan apabila suatu negara bertindak subordinasi terhadap kaum perempuan terhadap berbagai bidang. Metode yang digunakan dalam penelitian yaitu metode analisa deskriptif-kualitatif berbasis kajian kepustakaan (library research). Teknik analisis data dengan cara mengumpulkan berbagai macam literatur relevan yang memiliki ketersangkutpautan dengan permasalahan dalam penelitian ini. Hasil penelitian yang didapat ialah berdasarkan kajian literatur yakni terdapat beberapa dampak dari tindakan subordinasi perempuan salah satunya adalah ketidakadilan peran gender menjelang era bonus demografi tahun 2035.
\end{abstract}

Kata Kunci: Subordinasi Gender, Peran Perempuan, Pembangunan Nasional

\section{Abstract}

In facing the demographic bonus in 2035, of course, we must prepare from now on, including in subordinating women. The purpose of this research is to find out what are the impacts if a country acts in subordination to women in various fields. The method used in this research is descriptivequalitative analysis method based on library research (library research). The data analysis technique is by collecting various kinds of relevant literature that are related to the problems in this study. The results obtained are based on literature review, namely there are several impacts of women's subordination, one of which is the inequality of gender roles before the demographic bonus era in 2035.

Keywords: Gender Subordination, Role of Women, National Development

\section{PENDAHULUAN}

Gender merupakan istilah yang membedakan peranan dan hubungan sosial antara laki-laki dan perempuan, menurut patini (2013) gender merupakan pembangunan sosial budaya masyarakat yang dibentuk dalam menjalankan perananya masing masing (Thomson dan priestley,1996). yang membedakan karakter laki-laki dan perempuan disebut jenis kelamin (seks) yang bersifat kodrati dan tidak bisa dirubah karena hakikatnya datang dari sang pencipta. Berdasarkan sosial budaya perbedaan laki-laki dan perempuan (gender) menyangkut peranan, fungsi, tugas dan tanggung jawab di masyarakat. Sehingga gender bersifat dinamis dan berbeda di setiap wilayah selanjutnya menurut Davis (1991), Arber dan Gilbert, (1992) dalam parti (2013) konsep gender subordinasi perempuan merupakan suatu

Jurnal Cendekiawan Ilmiah PLS Vol 5 No 2 Desember 2020 
keuntungan bagi laki laki yang menjadi penyebab terjadinya ketidakadilan gender.

Ketidak adilan atau ketimpangan gender yang dikaitkan dengan ciri biologis terjadi pada perempuan, karena perempuan bersifat feminim, hal tersebut membuat perempuan dianggap sebagai individu yang lemah lembut dan keibuan, sedangkan laki-laki dianggap sebagai individu yang kuat dan tangguh sehingga perempuan menjadi sumber timbulnya subordinasi gender. Padahal gender sepenuhnya bersumber dari sudut pandang masyarakat yang tidak ada kaitannya dengan ciri fisik atau biologis. Perbedaan gender ini berasal kebiasaan sosial dan budaya masyarakat yang diajarkan secara turun termurun sehingga membuat manusia beranggapan bahwa demikianlah peran yang harus dijalankan. Subordinasi gender diartikan sebagai penomorduaan gender baik terjadi pada laki-laki maupun perempuan. Namun banyak kasus umumnya terjadi pada perempuan. Sehingga subordinasi perempuan merupakan penomorduaan perempuan, artinya peran, fungsi dan kedudukan perempuan berada di bawah laki-laki. Menurut Julia cleves mosse (1996) asal asul subordinasi perempuan yang terjadi tidak hanya dalam konteks keluarga melainkan juga hubungan peran antara laki laki dan perempuan yang berkaitan dengan pekerjaan. Dalam Safrudin.A. (2002) meskipun memiliki pendidikan yang tinggi perempuan berperan sebagai ibu dan istri sebagai bentuk penyerahan diri untuk menjadi seorang manager rumah tangga. Jika perempuan memiliki pekerjaan maka menjadi suatu problematika yang dihadapi perempuan hal ini sejalan pendapat montingo (Busye,34) dalam Masruroh.N. (2011) problem memiliki problema tentang pendidikan anak yang tidak mudah untuk digantikan kepada orang lain yang baik dan bertanggung jawab. Subordinasi perempuan nyaris membuat perempuan tidak ada nilainnya. Sebagaimana yang diungkapkan oleh Dede Wiliam de Vries dan Nurul Sutarti (2006) yang mengatakan bahwa "penomorduaan terhadap perempuan merupakan awal mula terjadinya ketidakadilan gender". Memposisikan perempuan dari sudut pandang laki-laki menjadikan posisi laki-laki lebih penting dari perempuan. Hal tersebut mempersempit bahkan terpinggirkannya peran perempuan di ranah publik dan hanya terbuka lebar di ranah domestik. Penomorduaan membuat perempuan tidak mendapatkan hak dan kesempatan berkontribusi dalam pembangunan nasional baik di bidang politik, ekonomi sosial dan budaya.

Padahal seiring dengan perkembangan era revolusi industry 4.0 bahkan menuju 5.0, kesetaraan gender menjadi hal yang relevan untuk ditingkatakan, sehingga antara perempuan dan laki-laki dapat bekerja sama dalam pembangunan nasional. Bahkan kesetaraan gender menjadi tujuan dari negara-negara di dunia yang dirumuskan dalam Millenium Development Goals (MDGs). Di Indonesia kesetaraan gender tercantum dalam INPRES Nomor 9 Tahun 2000 tentang Pengarusutamaan Gender (PUG) dalam Pembangunan Nasional. Sehingga dengan dijadikan kesetaraan gender sebagai tujuan dalam meningkatkan pembangunan nasional bahkan internasional, isu-isu ketidakadilan gender akan berkurang bahkan menghilang. Peran perempuan dalam kebijakan pembangunan nasional harus terus diperhatikan, karena peran perempuan mempunyai dampak yang 
penting dalam memutuskan mata rantai kemiskinan. Dalam kebijakan ODA (1989) dalam Julia cleves mosse (1996) perempuan memiliki akses bagi masyarakat jika memiliki pengetahuan dan keterampilan sehingga menjadi produktif secara ekonomis. Perbaikan kualitas perempuan khsusnya di bidang pendidikan menjadi tonggak dalam perbaikan kualitas satu generasi karena perempuan memiliki keistimewaan untuk mengandung dan melahirkan. Semakin baik kualitas perempuan akan semakin baik kualitas generasi berikutnya. Pendidikan perempuan mempunyai efek eksternalitas positif atas kuantitas dan kualitas pendidikan yang lebih baik bagi generasi mendatang. Peningkatan modal manusia akan meningkatkan tingkat investasi dan pertumbuhan ekonomi. Di sisi lain. Indonesia akan mengalami bonus demografi.

Berdasarkan penelitian McKinsey Global Institute (2012) dalam Agnes dkk (2016) Indonesia menuju tahapan bonus demografi, dimana kondisi struktur umur penduduk lebih banyak usia produktif. Untuk mendapatkan manfaat besar dari bonus demografi tersebut, sumber daya manusia harus baik dari sisi kesehatan, kecerdasan, dan pendidikan. Bahwa pada tahun 2030 Indonesia diperkirakan dapat meraih peringkat ke-7 terbesar di dunia dengan catatan kita memiliki sumber daya manusia terdidik dan perempuan juga masuk ke lapangan pekerjaan. Jika pemerintah mengabaikan kesetaraan gender, maka Indonesia dapat terjebak menjadi negara berpendapatan menengah. Berdasarkan uraian tersebut, tujuan dari penelitian ini adalah menganalisis penolakan dari adanya subordinasi gender terhadap kondisi ekonomi Indonesia menjelang bonus demografi tahun 2035.

\section{KAJIAN TEORI}

\section{A. Konsep Gender}

Secara Etimologis, gender bisa di definisikan sebagai harapan-harapan budaya terhadap laki-laki dan perempuan. Gender dipandang sebagai suatu konsep kultural yang dipakai untuk membedakan peran, perilaku, mentalitas dan karakteristik emosional antara laki-laki dan perempuan yang berkembang dalam masyarakat. Gender merupakan suatu sifat yang dijadikan dasar untuk mengidentifikasi perbedaan antara laki-laki dan perempuan dilihat dari segi kondisi dan sosial. Gender memiliki kedudukan yang penting dalam kehidupan seseorang melalui pengalaman hidup yang akan ditempuhnya. Gender dapat menentukan akses seseorang terhadap pendidikan, dunia kerja dan sektor-sektor publik lainnya. Gender juga dapat menentukan kesehatan, harapan hidup dan kebebasan gerak seseorang, akan menentukan seksualitas, hubungan dan kemampuan seseorang untuk membuat keputusan dan bertindak secara otonom.

Konsep gender yang dikembangkan Hubies (melalui Anshori, dkk 1997:25) dalam rokhmansyah.A.(2016) meliputi:

1) Gender difference, yaitu perbedaan-perbedaan karakter, perilaku, harapan yang dirumuskan untuk tiap-tiap orang menurut jenis kelamin. 
2) Gender Gap, yaitu perbedaan dalam hubungan berpolitik dan bersikap antara laki-laki dan perempuan.

3) Genderation, yaitu acuan konsep penempatan jenis kelamin pada identitas diri dan pandangan orang lain.

4) Gender Role, yaitu peran perempuan dan peran laki-laki yang diterapkan dalam bentuk nyata menurut budaya setempat yang dianut

\section{B. Pengertian Subordinasi (Penomorduaan)}

Subordinasi adalah suatu keyakinan yang menganggap salah satu jenis kelamin lebih penting atau lebih utama dibanding jenis kelamin lainnya. Baik itu laki-laki yang dianggap lebih unggul dari perempuan ataupun perempuan yang lebih unggul dari laki-laki. Nilai-nilai sosial dan budaya di masyarakat telah memilah-milah peran laki-laki dan perempuan. Perempuan dianggap bertanggungjawab dan memiliki peran dalam urusan domestik atau reproduksi, sementara laki-laki dalam urusan publik atau produksi. peran dan fungsi perempuan dalam urusan domestik dan reproduksi dalam penghargaan yang sama dengan peran publik dan produksi. Ataupun laki-laki bisa saja mendapat penghargaan dalam melaksanakan fungsi domestik. Hal ini merupakan akibat dari sistem dan struktur sosial yang menempatkan kaum laki-laki dan perempuan pada posisi yang merugikan.

\section{Pentingnya peran perempuan dalam pembangunan nasional}

Realitas ketidakadilan bagi kaum perempuan mulai dari marginalisasi, subordinasi yang merupakan separuh harga laki-laki, sebagai pembantu tergantung pada laki-laki dan bahkan sering diperlakukan dengan kasar atau setengah budak. Seakan memposisikan perempuan sebagai kelompok masyarakat kelas dua, yang berimbas pada berkurangnya hakhak perempuan termasuk hak untuk mendapatkan pendidikan. Kondisi di Indonesia dalam bidang pendidikan relatif masih sangat rendah dibandingkan laki-laki. Semakin tinggi tingkat pendidikan, semakin sedikit jumlah perempuan yang mengecapnya. Berdasarkan statistik PBB, "perempuan melakukan lebih dari $60 \%$ dari seluruh waktu kerja didunia, tetapi mereka hanya memperoleh $10 \%$ dari pendapatan dinia dan hanya memiliki $1 \%$ dari tanah di seluruh dunia" (Kamla Bhasin, 1993: 3-9).

Dalam konteks nasional, telah ada upaya-upaya untuk melibatkan perempuan dalam upaya pembangunan melalui beberapa kebijakan pemerintah telah mencanangkan strategi pembangunan yang dilakukan untuk mencapai kesetaraan dan keadilan gender melalui pengintregasian pengalaman, aspirasi, kebutuhan dan permasalahan perempuan dan laki-laki dalam perencanaan, pelaksanaan, pemantauan dan evaluasi dari seluruh kebijakan, program, proyek dan kegiatan diberbagai bidang kehidupan dan pembangunan. Peran perempuan dalam pembangunan negara bisa diukur dengan melihat peran perempuan di negara tersebut dalam pembangunan. Perempuan memiliki kedudukan yang sama dalam berusaha dan bekerja, laki-laki dan perempuan dapat bekerja sama dalam berbagai bidang kehidupan. Kemampuan perempuan semakin tampak dalam berbagai pekerjaan dan profesi serta

Jurnal Cendekiawan Ilmiah PLS Vol 5 No 2 Desember 2020

p-ISSN $2541-7045$ 
kualitas pekerjaannya pun tidak lebih rendah daripada laki-laki. Kemajuan dan karir yang dicapai perempuan jelas melalui perjuangan tanpa perbedaan atau diskriminasi gender.

Persamaan hak antara laki-laki dan perempuan di Indonesia pada saat ini termasuk dalam kepemimpinan dan partisipasi dalam bidang politik. Berbagai alasan yang melatar belakangi seorang perempuan dalam berperan diberbagai bidang kehidupan antara lain yaitu karena faktor ekonomi, adanya kesempatan yang diberikan oleh keluarga untuk menuntut ilmu sehingga memiliki keahlian yang memungkinkan untuk mengembangkan kariernya, serta karena kesadaran diri untuk mengembangkan diri dan karier. Dengan demikian perempuan memiliki peran ganda yaitu menjadi wanita karier dengan tanpa meningggalkan kodrat kewanitaannya. Upaya mencapai keseimbangan dalam menjalakan peran ganda tersebut jelas tidaklah mudah terutama sikap budaya masyarakat yang belum sepenuhnya menerima. Dibutuhkan kesadaran dan dukungan dari berbagai pihak dalam mengupayakan kesetaraaan gender.

\section{Bonus Demografi tahun 2035}

Secara historis, tanda-tanda munculnya fenomena bonus demografi di Indonesia dimulai pada awal tahun 1990-an melalui keberhasilan progam Keluarga Berencana. Adapun progam keluarga berencana ini dilakukan atas dasar logika developmentalisme. Asumsi yang dibangun adalah ketika populasi penduduk mengalami kelebihan kapasitas (overload) maka berimplikasi simetris dengan kemiskinan. Berbeda halnya dengan konsep keluarga berencana yang dilakukan di negara maju yang lebih berorientasi kepada pengendalian angka fertilitas, kebijakan keluarga berencana di negara berkembang diarahkan kepada perhitungan ekonomi dalam rangka memperbaiki kualitas hidup masyarakat sekaligus pula mengurangi kemiskinan sehingga beban ekonomi negara berkurang, maka pertumbuhan penduduk perlu dikekang. Periode bonus demografi di Indonesia dimulai tahun 2015-2035 dengan angka ketergantungan (dependency ratio berkisar antara 0,4-0,5 yang artinya bahwa setiap 100 orang usia produktif menanggung 4050 orang usia tidak produktif (Kompasiana.com). Proporsi usia anak-anak kurang dari 15 tahun akan terus berkurang dibandingkan dengan penduduk usia kerja. Berdasarkan data Survei Penduduk Antar Sensus (SUPAS 2015) jumlah ketergantungan tahun 2015 adalah 49,2 yang berarti setiap 100 penduduk usia produktif (15-64 tahun) menanggung beban sebanyak 49,2 penduduk usia non produktif (kurang dari 15 tahun dan 65 tahun keatas). Pada kesempatan bonus demografi ini, bangsa Indonesia mempunyai kesempatan besar memacu produktivitas dan pertumbuhan ekonomi dimana pertumbuhan ekonomi diharapkan meningkatkan kemajuan kemakmuran bangsa. Hal ini akan memberikan dampak pada peningkatan kesejahteraan yang terasa hingga berpuluh-puluh tahun kemudian.

\section{METODE PENELITIAN}

Penelitian ini menggunakan metode analisa deskriptif-kualitatif berbasis kajian kepustakaan (library research). Yang dimaksudkan sebagai analisa deskriptif kualitatif ialah

Jurnal Cendekiawan Ilmiah PLS Vol 5 No 2 Desember 2020

p-ISSN $2541-7045$ 
analisis yang didasarkan pada pemetaan permasalahan yang terdapat dalam dua variabel kasus yang kemudian dicari titik korelasinya menolak, dan seimbang berdasarkan pada pengumpulan data yang dilakukan oleh peneliti. Adapun studi kepustakaan sendiri merupakan instrumentasi penelitian dengan mengumpulkan berbagai macam literatur relevan yang memiliki ketersangkut pautan dengan permasalahan dalam penelitian ini.

Adapun langkah-langkah yang ditempuh dalam menganalisis data di lapangan adalah pertama, melakukan studi pendahuluan dengan meneliti kajian-kajian penelitian terdahulu yang membahas mengenai masalah Subordinasi Gender dan Bonus demografi di Indonesia kedua, mengumpulkan literatur relavan sesuai dengan fokus permasalahan yang diangkat sebagai tema utama dalam penelitian ini. Ketiga, menganalisis secara kritis berbagai sumber literatur tersebut untuk mendapatkan pemahaman mendasar mengenai korelasi subordinasi gender dengan bonus demografi. Keempat, melakukan komparasi dengan data lain untuk menemukan fokus korelasi dan permasalahannya. Kelima menulis makalah berdasarkan argumentasi analisis dari berbagai data tersebut

\section{HASIL DAN PEMBAHASAN}

\section{Menolak Subordinasi Gender Berdasarkan Pentingnya Peran Perempuan Dalam Pembangunan Nasional Menjelang Bonus Demografi 2035}

Subordinasi gender adalah penomorduaan gender baik terjadi pada laki-laki maupun perempuan, subordinasi gender memposisikan salah satu gender lebih unggul dari gender lainnya. Umumnya subordinasi gender terjadi pada perempuan karena kondisi sosial dan budaya yang membuat perempuan lebih berperan di ranah domestik membatasi ruang lingkup perempuan untuk berkembang. Dan walaupun perempuan berperan di ranah public, tugas perempuan menjadi dua yaitu di ranah domestic dan publik. Dampak dari subordinasi perempuan terhadap pembangunan nasional, Rendahnya partisipasi perempuan ditemukan dalam berbagai level dan bidang kegiatan pembangunan pada negara-negara berkembang. Meskipun perempuan dan anak perempuan menjadi pemikul langsung beban terberat dari subordinasi ini, beban ini akan diderita juga oleh masyarakat, dan pada akhirnya akan merugikan setiap orang. Ketertinggalan perempuan dalam ketenagakerjaan tercermin dari sumbangan pendapatan yang jauh lebih rendah dari laki-laki serta proporsi pengangguran yang lebih tinggi dari laki-laki. Sumbangan pendapatan perempuan di KLU berada pada kisaran 25 persen, sementara sumbangan.

Untuk mendongkrak keterpurukan keluarga-keluarga seperti itu sangat perlu peran serta perempuan. Untuk diberdayakan dalam membantu perekonomian keluarga dan membantu suaminya dalam mencari nafkah. Karena setiap individu khususnya perempuan memiliki kekuatan dan kemampuan yang menjadi sumber penggerak menurut indrajit.w.(2014) setiap individu dengan kapasitas unggul memiliki kemampuan dan keyakinan diri untuk mewujudkan cita citanya dalam mengembangkan kehidupanya, walaupun proses perubahan yang di rencanakan, atau perbaikan kondisi menuju ke arah

Jurnal Cendekiawan Ilmiah $\mathcal{P} \mathcal{L} S$ Vol 5 No 2 Desember 2020

p-ISSN $2541-7045$ 
yang lebih baik. Banyak kendala yang dihadapi terutama terkait dengan kontruksi sosial terhadap peran, fungsi dan kedudukan dari perempuan sendiri maupun dengan budaya setempat.

Keadilan gender adalah hak yang sama antara perempuan dan laki-laki. Terwujudnya kesetaran dan keadilan gender ditandai dengan tidak adanya diskriminasi antara perempuan dan laki-laki, dan dengan demikian mereka memiliki akses, kesempatan berpartisipasi, dan kontrol atas pembangunan serta memperoleh manfaat yang setara dan adil dari pembangunan. Memiliki akses dan partisipasi berarti memiliki peluang atau kesempatan untuk menggunakan sumber daya dan memiliki wewenang untuk mengambil keputusan terhadap cara penggunaan dan hasil sumber daya tersebut. Terwujudnya kesetaran dan keadilan gender ditandai dengan tidak adanya diskriminasi antara perempuan dan laki-laki, dengan demikian mereka memiliki akses, kesempatan berpartisipasi, dan kontrol atas pembangunan serta memperoleh manfaat yang setara dan adil dari pembangunan. Analisis yang digunakan dengan menggunakan analisis gender yaitu menganalisis data dan informasi secara sistematis tentang perempuan dan laki-laki untuk mengidentifikasi dan mengungkap kedudukan, fungsi, peran, tanggung jawab dan faktor-faktor yang mempengaruhi kesetaraan gender. Menjelang bonus demografi 2035 menurut Raharjo Jati.W (2015) yaitu jumlah penduduk usia produktif akan mendominasi penduduk usia anak dan usia tua. Hal tersebut harus dimanfaatkan sebaik mungkin melalui peningkatan kualitas penduduk usia muda dengan cara peningkatan pendidikan dan keterampilan. Sehingga semakin tinggi pendidikan dan keterampilan yang dimiliki masyarakat, semakin tinggi juga peningkatan pertumbuhan ekonomi. Dengan adanya kesetaraan gender, menurut Herry Jogaswara (2020) pentinya peran perempuan untuk meningkatkan sumberdaya manusia yang berkualitas dalam menghadapi bonus demografi serta pentingnya kesetaaraan gender sebagai pondasi terbanguna ketahanan keluarga yang kokoh dalam mendukung kesempatan perempuan untuk mendapatkan hak yang sama dan berperan dalam ranah publik, semakin besar tingkat partisipasi kerja perempuan berdampak positif pada pertumbuhan ekonomi, dan bonus demografi dapat dimanfaatkan secara maksimal dalam mewujudkan Indonesia yang maju.

\section{SIMPULAN DAN SARAN}

\section{A. Simpulan}

Berdasarkan hasil penelitian dan pembahasan yang telah dilakukan, maka peneliti dapat menarik kesimpulan sebagai berikut: Menolak adanya subordinasi gender terutama yang dialami kaum perempuan karena subordinasi akan menghambat laju pembangunan di bidang ekonomi bagi bangsa dan negara Indonesia, perekonomian Indonesia tidak bisa dikatakan maju hanya dengan mengandalkan kaum laki-laki untuk memajukan pembangunan maka keterlibatan kaum perempuan sangat di butuhkan dalam mengembangkan perekonomian bangsa. subordinasi gender merupakan penomorduaan yang terjadi pada laki-laki maupun

Jurnal Cendekiawan Ilmiah PLS Vol 5 No 2 Desember 2020

p-ISSN $2541-7045$ 
perempuan yang dibuktikan dengan budaya masyarakat yang memposisikan perempuan untuk lebih banyak berperan di ranah domestik dan membatasi perempuan di ranah publik. peran perempuan dalam ranah publik sangat membantu dalam menciptakan peningkatan pertumbuhan ekonomi terutama menjelang bonus demografi tahun 2035. Maka dalam upaya mengatasinya perlu adanya komitmen dan peran gender atas dasar kesepakatan bersama dalam keluarga. Bonus demografi adalah penduduk usia produktif mendominasi usia anak dan usia tua. Sehingga banyaknya masyarakat usia produktif harus diimbangi dengan kualitas masyarakat melalui kesetaraan gender dalam bidang pendidikan dan keterampilan yang akan mendorong terciptanya lapangan perkerjaan yang mampu menampung lonjakan penduduk usia produktif pada masa-masa bonus demografi.

\section{B. Saran}

Berdasarkan pembahasan kesimpulan dari atas, maka berikut saran dari penulis:

1. Perlunya pendidikan keluarga/pendidikan parenting yang di selenggarakan di lembaga baik formal maupun non formal

2. Perlu adanya bimbingan/penyuluhan terkait dalam menjalankan peran gender dalam keluarga

3. Adanya aturan yang jelas dari tiap lembaga/perusahaan yang mempekerjakan perempuan berdasarkan peran gender dan perlindungan hukum khususnya terhadap perempuan dan anak

DAFTAR PUSTAKA

Agnes Vera Yanti Sitorus (2016) Dampak Ketimpangan Gender Terhadap Pertumbuhan Ekonomi Di Indonesia. https://doi.org/10.33007/inf.v2i1.190 https://ejournal.kemsos.go.id/index.php/Sosioinforma/article/view/190/440

Brainly. Pengertian Subordinasi. Tersedia (Online) https://brainly.co.id Diakses pada [17-102020]

Badan Pusat Statistik. 2015. Penduduk Indonesia Hasil Supas 2015. (online) Tersedia di https://www.bps.go.id/publicaion/2015/11/30/41ccbadf0bb914534f5c08a62/pendudu k-indonesia-hasil-supas-2015.html Diakses pada [ 8 November 2020].

Herry Jogaswara. (2020). Pusat Penelitian Kependudukan http://lipi.go.id/siaranpress/kesetaraan-gender-dan-ketahanan-keluarga-sebagaipondasi-pembentukan--sdm-unggul-/21807.

Julia cleves mosse (1996) Gender dan pembangunan. Yogyakarta.Rifka Annisa \&Pustaka Pelajar.

Indrajit.w. (2014) Pemberdayaan masyarakat dan pembangunan gagasan manajemen pengembangan masyarakat untuk memutus mata rantai kemiskinan Jatim. Intrans Publishing. 
Kompasiana.com. Mengawal Bonus Demografi 2020-2035 Tersedia di https;//www.google.com/amp/s/www.kompasiana.om/amp/esra88923/5d6fbf4c097f 3672e06b19c2/mengawal bonus demografi 2020-2035. Diakses pada 8 November 2020

Masruroh, N (2011) Perempuan karier dan pendidikan anak idelitas pola pembelajaran play group. Semarang. RaSAIL Media group.

Parti (2013) Bias gender Dalam Birokrasi. Yogyakarta Tiara Wacana

Rokhmansyah, Alfian. 2016. Pengantar Gender dan Feminisme Pemahaman Awal Kritik Sastra Feminisme. Yogyakarta: Garudhawaca.

Safrudin.A. (2002) pendidikan keluarga konsep dan strategi. Yogyakarta.Gave Media

Abidin, Y. Et al (2014). Kemampuan Menulis dan Berbicara Akademik. Bandung: Rizqy Press.

Sitorus, Agnes Vera Yanti. 2016. Dampak ketimpangan gender terhadap pertumbuhan ekonomi indonesia. Jurnal kesejahtraan sosial. Vol 2. No 1. Hal 89-90 dan 92.

Syafe'I, Imam. 2015. Subordinasi perempuan dan implikasi terhadap rumah tangga. Jurnal studi keislaman. Vol 15 no 1 hal 146.

Wasisto, Raharjo Jati (2015) Bonus Demografi Sebagai Mesin Pertumbuhan Ekonomi: Jendela Peluang Atau Jendela Bencana Di Indonesia? Peneliti Lembaga Ilmu Pengetahuan Indonesia (LIPI). Email: wasisto.raharjo@mail.ugm.ac.id, Populasi Volume 23 Nomor 1. https://jurnal.ugm.ac.id/populasi/article/view/8559.

UU No 23 Tahun 2004 Tentang Penghapusan Kekerasan. Dalam Rumah Tangga.

INPRES Nomor 9 Tahun 2000 tentang Pengarusutamaan Gender (PUG). 